\title{
In vitro metabolic stability of iodinated obestatin peptides
}

\author{
Bart De Spiegeleer $^{\mathrm{a}, *}$, Sylvia Van Dorpe ${ }^{\mathrm{a}}$, Valentijn Vergote ${ }^{\mathrm{a}}$, Evelien Wynendaele ${ }^{\mathrm{a}}$, Ewald Pauwels ${ }^{\mathrm{b}}$, \\ Christophe Van De Wiele ${ }^{\mathrm{c}}$, Pablo Garcia-Solis ${ }^{\mathrm{d}}$, Juan Carlos Solis-Sainz ${ }^{\mathrm{d}}$ \\ a Drug Quality and Registration (DruQuaR) Group, Faculty of Pharmaceutical Sciences, Ghent University, Harelbekestraat 72, B-9000 Ghent, Belgium \\ ${ }^{\mathrm{b}}$ Department of Subatomic and Radiation Physics, Faculty of Sciences, Ghent University, Ghent, Belgium \\ c Department of Nuclear Medicine, Faculty of Medicine, Ghent University, De Pintelaan 185, B-9000 Ghent, Belgium

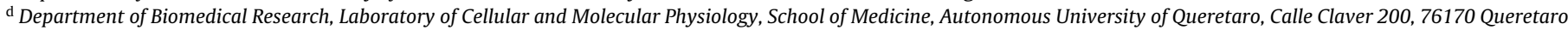 \\ Mexico
}

\section{A R T I C L E I N F O}

\section{Article history:}

Received 14 November 2011

Received in revised form

18 December 2011

Accepted 18 December 2011

Available online 27 December 2011

\section{Keywords:}

Peptide iodination

In vitro metabolic stability

Proteases

Deiodinases

Peptidomimetics

\begin{abstract}
A B S T R A C T
Different iodinated mouse obestatin peptides have been characterized toward their in vitro stability in the main metabolic compartments plasma, liver and kidney. Using HPLC-UV for quantification, significant differences in the degradation kinetics of the iodinated peptides, arising from both enzymatic proteolysis and dehalogenation, were found when compared to the native, unmodified peptide. HPLC-MS/MS analysis demonstrated that the cleavage sites were dependent upon the biological matrix and the location of the amino acid residue incorporating the iodine atom(s). The degrading proteases were found to target peptide bonds further away from the iodine incorporation, while proteolytic cleavages of nearby peptide bonds were more limited. Diiodinated amino acid residue containing peptides were found to be more susceptible to deiodination than the mono-iodinated derivative. In plasma, the percentage of peptide degradation solely attributed to deiodinase activity after 20 min incubation reached up to $25 \%$ for 2,5 -diiodo- $\mathrm{H}^{19}$-obestatin compared to $20 \%$ and only $3 \%$ for $\left(3,5\right.$-diiodo- $\mathrm{Y}^{16}$ )- and (3-iodo- $\mathrm{Y}^{16}$ ) obestatin, respectively. Hence, our results demonstrate that the different iodinated peptides pose significantly different metabolization properties and thus, also different biological activities are expected for peptides upon iodination.
\end{abstract}

(c) 2011 Elsevier Inc. All rights reserved.

\section{Introduction}

Obestatin is a recently discovered 23 amino acid peptide derived from the processing of the ghrelin gene, and has been claimed to be a functional opponent of ghrelin (suppressing food intake) making it a potential lead against obesity [32]. Although the in vivo activity is increasingly being confirmed by a number of research groups $[4,5,10,17,20]$, many also failed to show inhibitory effects on food and water intake [26]. Also, the underlying mechanism still remains unclear as demonstrated by numerous contradictory findings and a declaration by the discoverers of obestatin

Abbreviations: m-Obestatin, Mouse obestatin; 2,5-Diiodo-H, Diiodination on the histidine amino acid residue; 2-Iodo- $\mathrm{H}$, Monoiodination on the histidine amino acid residue; 3,5-Diiodo-Y, Diiodination on the tyrosine amino acid residue; 3 Iodo-Y, Monoiodination on the tyrosine amino acid residue; MIT, Monoiodinated tyrosine; DIT, Diiodinated tyrosine; MIH, Monoiodinated histidine; DIH, Diiodinated histidine; ID or DI, Iodothyronine deiodinase; IYD, Iodotyrosine deiodinase; DIP, Diiodinated peptide; MIP, Mono-iodinated peptide; NIP, Non-iodinated peptide; M, Proteolytic metabolite.

* Corresponding author. Tel.: +32 9264 8100; fax: +32 92648193.

E-mail address: Bart.DeSpiegeleer@UGent.be (B. De Spiegeleer). that even they cannot reproduce all their original findings without paying attention to e.g. specific (circadian) time-effects [31]. In attempts to explain the conflicting results on obestatin, several functional quality issues have been investigated in detail: presence of synthesis impurities in commercially available peptides [6] and formation of mixtures during radio-iodination [27,28]. As for most endogenous-derived peptide leads, obestatin has only little resistance to systemic plasma and tissue proteases [29] which may result in a failure to demonstrate convincing in vivo effects [30]. The major in vitro plasma metabolic pathways of m-obestatin have been shown to involve cleavage between residues $\mathrm{F}^{1}-\mathrm{N}^{2}$ and $\mathrm{P}^{4}-\mathrm{F}^{5}$, with several other peptide bonds also being vulnerable to proteolytic activity $\left(D^{6}-V^{7}, Y^{16}-Q^{17}, G^{20}-R^{21}, R^{21}-A^{22}\right.$ and $\left.A^{22}-L^{23}\right)$. Currently, some recent studies investigated fragments or modified obestatin derivatives to provide protection against enzymatic degradation. Substitutions at $G^{3}$ and $G^{8}$ by $\alpha$-aminoisobutyric acid and at $\mathrm{F}^{5}$ by cyclohexylalanine yielded promising insights into the structural requirements [19], while pegylated obestatin was found to be three times more stable than native obestatin [2]. Using the obestatin fragments $\{1-10\}$ and $\{11-23\}$, some structure-activity properties were defined [24]. The influence of obestatin iodination on its functional behavior, of which the enzymatic degradation is an 
important aspect, has not yet been described in detail for the different possible derivatives (i.e. mono- and diiodinated on $\mathrm{Y}^{16}$ and $\mathrm{H}^{19}$ ), although these iodinated obestatines are used throughout biomedical studies. Moreover, the enzymatically catalyzed dehalogenation of iodinated peptides has not yet been investigated, despite its importance.

The aim of the present study was to investigate the effect of iodine incorporation at $\mathrm{Y}^{16}$ and $\mathrm{H}^{19}$ on the resistance of $\mathrm{m}$-obestatin against in vitro degradation in the main biological tissues (plasma, liver and kidney), encompassing proteolysis as well as deiodination. These data are not only important for the study of dehalogenation of peptides in general, but also for the generation of new peptidomimetics with improved stability characteristics and the interpretation of biomedical test results involving ${ }^{125} \mathrm{I}-,{ }^{123} \mathrm{I}-$ or ${ }^{131}$ I-labeled peptides.

\section{Materials and methods}

\subsection{Peptides and other materials}

All peptides used ( $c f$. Table 1 ) were of $\geq 95.0 \%$ peptide purity, as verified by HPLC-UV analysis [6]. Unmodified mouse obestatin was obtained from California Peptide Research (Napa, CA, USA). Iodinated mouse obestatin derivatives (i.e. (3-iodo- $\left.\mathrm{Y}^{16}\right)$ obestatin, (3,5-diiodo- $\left.\mathrm{Y}^{16}\right)$-obestatin, (2,5-diiodo- $\left.\mathrm{H}^{19}\right)$-obestatin and $\left(3,5\right.$-diiodo- $\mathrm{Y}^{16}, 2,5$-diiodo- $\left.\mathrm{H}^{19}\right)$-obestatin; all prepared using Fmoc-chemistry) were purchased from Bachem (Bubendorf, Switzerland). Heparinized NMRI mouse plasma and male ICR CD1 mice were obtained from Harlan (Horst, Netherlands). Modified Lowry Protein Assay Kit was purchased from Pierce Biotechnology (Rockford, IL, USA), and used according to the instructions of the supplier. All other reagents were of analytical grade or better.

The following relative area response factors were calculated for UV detection at $195 / 215 \mathrm{~nm}$ with reference to an equimolar quantity of the native obestatin: 1.08/1.59, 1.14/1.80,1.00/1.18 and $1.11 / 1.77$ for (3-iodo- $\left.\mathrm{Y}^{16}\right)$-obestatin, (3,5-diiodo- $\left.\mathrm{Y}^{16}\right)$-obestatin, $\left(2,5\right.$-diiodo- $\left.\mathrm{H}^{19}\right)$-obestatin and $\left(3,5\right.$-diiodo- $\mathrm{Y}^{16}, 2,5$-diiodo- $\left.\mathrm{H}^{19}\right)$ obestatin, respectively. These values were used in the LC-UV kinetics.

\subsection{Preparation of homogenates}

After cervical dislocation, mouse organs were cleaned and transferred into ice-cold Krebs-Henseleit buffer pH 7.4 containing $0.2 \%$ $(\mathrm{w} / \mathrm{v})$ of $\mathrm{D}$-glucose, followed by homogenization for approximately 1 min using a rotor-stator type homogenizer. After sedimentation for $30 \mathrm{~min}$ at $5{ }^{\circ} \mathrm{C}$ to remove the larger particles, the middle layer was taken as final homogenate, with aliquots stored at $-35^{\circ} \mathrm{C}$ until further use. Prior to use, the protein content of each homogenate was determined using the Pierce Modified Lowry Protein Assay method.

\subsection{In vitro metabolic stability testing}

In vitro metabolic stability testing was determined using previously described procedures [30]. In brief, $90 \mu \mathrm{g}$ of peptide was incubated in Krebs-Henseleit buffer pH 7.4 with plasma/tissue homogenate added ( $600 \mu \mathrm{l}$ of mouse plasma, $900 \mu \mathrm{g}$ of liver protein, or $300 \mu \mathrm{g}$ of kidney protein) at $37^{\circ} \mathrm{C}$ while shaking. At predetermined time intervals, aliquots were immediately transferred into microtubes containing 1:10 volume of $10 \%(\mathrm{v} / \mathrm{v})$ formic acid solution in water. The enzyme reaction was stopped by heating at $95^{\circ} \mathrm{C}$ for $5 \mathrm{~min}$. Next, the sample is centrifuged to precipitate the denatured proteins and collect the supernatant for subsequent HPLC analysis. Similarly, appropriate placebos, controls and reference solutions were prepared as well. Experiments were carried out in duplicates. Assuming first-order kinetics, the rate constant $k$ was obtained from $\ln \left(P_{t} / P_{t_{0}}\right)=-k t$, from which the metabolic half-life was determined as $t_{1 / 2}=\ln (2) / \kappa$.

\subsection{Liquid chromatography}

The HPLC-PDA apparatus consisted of a Waters Alliance 2695 separations module, a Waters 2996 photodiode array detector and a Waters 2475 multi-wavelength fluorescence detector with Empower 2 software for data acquisition (all Waters, Milford, MA, USA). For PDA detection, the UV spectrum was recorded between 190 and $400 \mathrm{~nm}$.

The HPLC-UV/MS apparatus consisted of a Spectra System SN4000 interface, a Spectra System SCM1000 degasser, a Spectra System P1000XR pump, a Spectra System AS3000 autosampler and a Finnigan LCQ Classic ion trap mass spectrometer in positive ion mode (all Thermo, San José, CA, USA) equipped with a Waters 2487 dual wavelength UV detector (Waters, Milford, MA, USA) and XCalibur 2.0 software (Thermo, San José, CA, USA) for data acquisition. From the total ion chromatogram (TIC), extracted ion chromatograms (EICs) were obtained at selected $\mathrm{m} / \mathrm{z}$ values. Tandem mass spectrometry (MS/MS) data on obestatin peptides and their metabolites were examined using SEQUEST ${ }^{\circledR}$ available in BioWorks 3.3.1 software (Thermo, San José, CA, USA) based upon a FASTA file containing the obestatin sequences.

HPLC analysis was performed using an Everest $\mathrm{C}_{18}$ 238EV54 $(250 \mathrm{~mm} \times 4.6 \mathrm{~mm}$ I.D., $300 \AA$, $5 \mu \mathrm{m}$ particle size) column (Grace Vydac, Hesperia, CA, USA) in an oven set at $30^{\circ} \mathrm{C}$, with the following solvent system: (A) $0.1 \%(\mathrm{w} / \mathrm{v})$ formic acid in water, and (B) $0.1 \%$ $(\mathrm{w} / \mathrm{v})$ formic acid in acetonitrile. The gradient used for the separation was: $95 \% A+5 \% B$ from 0 to 5 min, followed a linear ramp from 5 to $65 \mathrm{~min}$ going to $75 \% \mathrm{~A}+25 \% \mathrm{~B}$. The flow rate was set at $1.0 \mathrm{ml} / \mathrm{min}$. The percentage of dehalogenation at the $20 \mathrm{~min}$ time point was estimated using the LC-MS data from the (diiodo)-, (monoiodo)- and (noniodo)-peptides, i.e. the non-proteolytic peptides only.

\section{Results}

Although iodine incorporation is considered to potentially hinder peptide breakdown by protease activity, a statistically significant (i.e. based upon the 95\% confidence intervals) increase in half-life time was only observed for $(3,5$-diiodo-Y16)-obestatin in plasma and for (3-iodo- $\left.Y^{16}\right)$-obestatin in liver homogenate (Fig. 1). The in vitro first-order degradation kinetic results obtained on the different iodinated obestatin derivatives in different biological matrices using UV detection at $195 \mathrm{~nm}$ are summarized in Table 2. Tetra-iodinated obestatin did not give consistent quantitative results due to excessive adsorption to containers and biological matrices. Several obestatin metabolites arising from proteolytic activity were observed using (tandem) mass spectrometry, being above the limit of detection of $0.02 \%$ relative to the parent peptide. Fig. 2 reflexes the relative importance of the different peptides found, resulting from the cleavage of the indicated peptide bond compared to the total quantity of degradants. For non-iodinated mouse obestatin incubated in mouse plasma, liver and kidney (data not shown), the obtained proteolytic fragments were consistent with a previous study [29].

In addition to the proteolytic degradation, significant dehalogenation was observed for the iodinated derivatives, especially for $\left(2,5\right.$-diiodo- $\left.\mathrm{H}^{19}\right)$-obestatin incubated in plasma as depicted in Fig. 3. From Table 3, it is obvious that iodine atom(s) removal in plasma and liver homogenate increases in the following order: (3iodo- $\left.\mathrm{Y}^{16}\right)$-, (3,5-diiodo- $\left.\mathrm{Y}^{16}\right)$ - and (2,5-diiodo- $\left.\mathrm{H}^{19}\right)$-obestatin. The percentage of peptide degradation solely attributed to deiodinase activity after $20 \mathrm{~min}$ incubation reached up to $25.5 \%$ for 
Table 1

Obestatin and its iodinated derivatives tested.

\begin{tabular}{|c|c|c|c|}
\hline \# & Peptide & Sequence & $M_{\mathrm{r}}(\mathrm{g} / \mathrm{mol})$ \\
\hline 1 & Rat/mouse obestatin & FNAPFDVGIKLSGAQYQQHGRAL-NH & 2516.82 \\
\hline 2 & $\left(3-\right.$ Iodo-Y $\left.{ }^{16}\right)$-obestatin & FNAPFDVGIKLSGAQI ${ }_{1}$ YQQHGRAL-NH & 2642.72 \\
\hline 3 & $(3,5$-Diiodo-Y16)-obestatin & FNAPFDVGIKLSGAQI $_{2}$ YQQHGRAL-NH $\mathrm{N}_{2}$ & 2768.61 \\
\hline 4 & $\left(2,5\right.$-Diiodo- $\left.\mathrm{H}^{19}\right)$-obestatin & FNAPFDVGIKLSGAQYQQI ${ }_{2} \mathrm{HGRAL} \mathrm{NH}_{2}$ & 2768.61 \\
\hline 5 & $\left(3,5\right.$-Diiodo- $Y^{16} 2,5$-Diiodo-H $\left.{ }^{19}\right)$-obestatin & FNAPFDVGIKLSGAQI $_{2} \mathrm{YQQI}_{2} \mathrm{HGRAL} \mathrm{NH}_{2}$ & 3020.40 \\
\hline
\end{tabular}

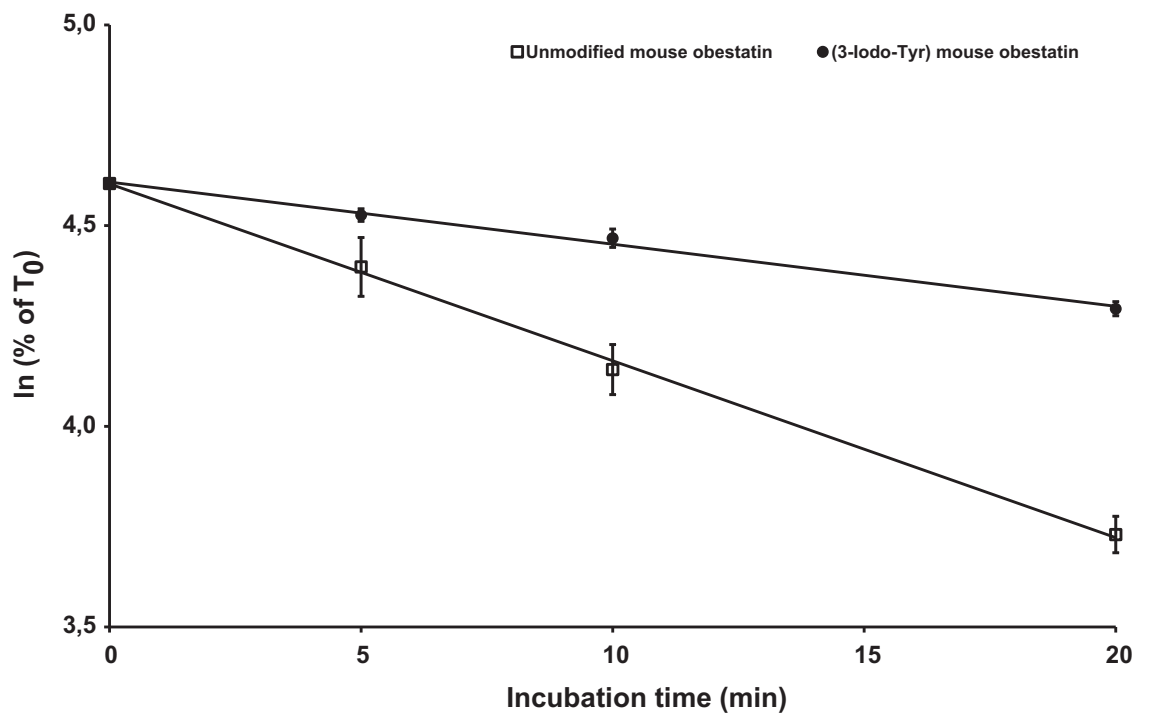

Fig. 1. Time-dependent decrease of native and mono-iodinated $\mathrm{Y}^{16}$ mouse obestatin upon incubation in liver homogenate. Data are expressed as mean \pm SEM.

Table 2

Half-life times of obestatin derivatives in biological matrices.

\begin{tabular}{|c|c|c|c|}
\hline \multirow[t]{2}{*}{ Peptide } & \multicolumn{3}{|c|}{ Half-life (min) [95\% C.I.] } \\
\hline & Plasma & Liver homogenate & Kidney homogenate \\
\hline Mouse obestatin & $16.8[15.2,18.7]$ & $15.7[13.5,18.9]$ & $7.0[4.7,13.9]$ \\
\hline (3-Iodo-Y $\left.{ }^{16}\right)$-obestatin & $14.7[11.2,21.2]$ & $41.5[37.7,46.3]$ & $10.9[8.8,14.5]$ \\
\hline$\left(3,5\right.$-Diiodo- $\left.Y^{16}\right)$-obestatin & $26.9[20.9,37.9]$ & $14.2[10.1,24.1]$ & $18.8[12.0,43.6]$ \\
\hline$\left(2,5\right.$-Diiodo- $\left.\mathrm{H}^{19}\right)$-obestatin & $16.7[11.4,31.3]$ & $18.4[13.6,28.3]$ & $13.2[8.2,35.0]$ \\
\hline
\end{tabular}

2,5-diiodo- $\mathrm{H}^{19}$-obestatin in plasma, the remainder being proteolysis (34.5\%) and intact peptide (40\%). In liver, about half of the quantity of dehalogenation products were formed compared to plasma, attaining $11.2 \%$ for 2,5 -diiodo- $\mathrm{H}^{19}$-obestatin, together with $43.1 \%$ proteolytic fragments and $45.7 \%$ of the parent peptide. In vitro dehalogenation was also observed in kidney homogenate, although to a much lesser extent when compared to plasma and liver, being below $1 \%$. However, because deiodination of proteolytic metabolites, nor proteolysis of deiodinated products, was taken into account, the percentage deiodination is actually underestimated. The conceptual scheme is visualized in Fig. 4. Especially when the percentage of deiodination was found to be rather high, several metabolites arising from a combination of dehalogenation and proteolysis were observed as well. This phenomenon is illustrated for (2,5-diiodo- $\left.\mathrm{H}^{19}\right)$-obestatin in mouse plasma, which was cleaved at the $\mathrm{F}^{5}-\mathrm{D}^{6}$ bond combined with the loss of a single iodine atom, yielding DVGIKLSGAQYQQI ${ }_{1} \mathrm{HGRAL} \mathrm{NH}_{2}$. The total ion chromatogram demonstrated a retention time of $31.1 \mathrm{~min}$ for this proteolysis-dehalogenation product, showing three peaks in the mass spectrum with $\mathrm{M}+2 \mathrm{H}^{2+}=1033.9, \mathrm{M}+3 \mathrm{H}^{3+}=689.6$ and $\mathrm{M}+4 \mathrm{H}^{4+}=517.5$. Its identity was further confirmed using the (tandem) mass spectrum (Fig. 5). This product may originate from two different pathways: (1) proteolysis of 2-iodo- $\mathrm{H}^{19}$-obestatin obestatin (i.e. dehalogenation followed by proteolysis) or (2) deiodination of the $\mathrm{F}^{5}-\mathrm{D}^{6}$ metabolite fragment, which was first formed from (2,5-diiodo- $\left.\mathrm{H}^{19}\right)$-obestatin. Both in plasma and liver homogenate, the peptide bond between $\mathrm{F}^{5}$ and $\mathrm{D}^{6}$ was found to be more susceptible to proteolytic cleavage for the iodinated peptide

Table 3

Dehalogenation: non-/mono-/diiodinated obestatin area \% at $T_{20} \min$ using HPLC-MS and percentage estimated.

\begin{tabular}{|c|c|c|c|}
\hline Peptide & Plasma & Liver homogenate & Kidney homogenate \\
\hline$\left(3\right.$-Iodo-Y $\left.{ }^{16}\right)$-ob & 8.8/91.2/NA [3.1\%] & 2.6/97.4/NA [2.0\%] & ND/100.0/NA [0.0\%] \\
\hline$\left(3,5\right.$-Diiodo-Y $\left.{ }^{16}\right)-o b$ & ND/24.1/75.9 [19.9\%] & 0.5/7.9/91.6 [7.1\%] & ND/1.8/98.2 [0.86\%] \\
\hline$\left(2,5-\right.$ Diiodo-H $\left.{ }^{19}\right)-o b$ & $18.9 / 20.2 / 60.9[25.5 \%]$ & $0.3 / 19.4 / 80.3[11.2 \%]$ & ND/1.9/98.1 [0.47\%] \\
\hline
\end{tabular}

NA: not applicable; ND: not detectable as below the limit of detection, being $2.14 \times 10^{-2} \%$. 
Plasma

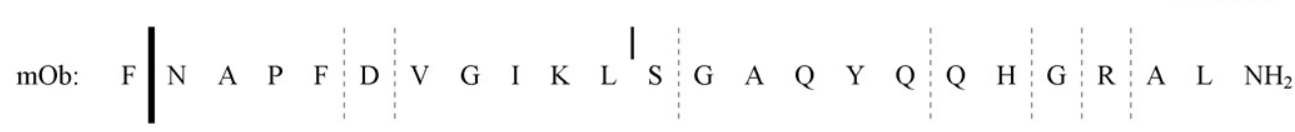

$$
\begin{aligned}
& \begin{array}{ll|llll|llllllllllllllll|lllll}
\text { I }_{1} Y m O b: & \mathrm{F} & \mathrm{N} & \mathrm{A} & \mathrm{P} & \mathrm{F} & \mathrm{D} & \mathrm{V} & \mathrm{G} & \mathrm{I} & \mathrm{K} & \mathrm{L} & \mathrm{S} & \mathrm{G} & \mathrm{A} & \mathrm{Q} & \mathrm{I}_{1} \mathrm{Y} & \mathrm{Q} & \mathrm{Q} & \mathrm{H} & \mathrm{G} & \mathrm{R} & \mathrm{A} & \mathrm{L} & \mathrm{NH}_{2}
\end{array} \\
& \begin{array}{ll|llll|llllllllllllllll|llllll}
\mathrm{I}_{2} \text { YmOb: } & \mathrm{F} & \mathrm{N} & \mathrm{A} & \mathrm{P} & \mathrm{F} & \mathrm{D} & \mathrm{V} & \mathrm{G} & \mathrm{I} & \mathrm{K} & \mathrm{L} & \mathrm{S} & \mathrm{G} & \mathrm{A} & \mathrm{Q} & \mathrm{I}_{2} \mathrm{Y} & \mathrm{Q} & \mathrm{Q} & \mathrm{H} & \mathrm{G} & \mathrm{R} & \mathrm{A} & \mathrm{L} & \mathrm{NH}_{2}
\end{array} \\
& \begin{array}{ll|llll|llllllllllllllll|lllllll}
\mathrm{I}_{2} \mathrm{HmOb}: & \mathrm{F} & \mathrm{N} & \mathrm{A} & \mathrm{P} & \mathrm{F} & \mathrm{D} & \mathrm{V} & \mathrm{G} & \mathrm{I} & \mathrm{K} & \mathrm{L} & \mathrm{S} & \mathrm{G} & \mathrm{A} & \mathrm{Q} & \mathrm{Y} & \mathrm{Q} & \mathrm{Q} & \mathrm{I}_{2} \mathrm{H} & \mathrm{G} & \mathrm{R} & \mathrm{A} & \mathrm{L} & \mathrm{NH}_{2}
\end{array}
\end{aligned}
$$

\section{Liver homogenate}

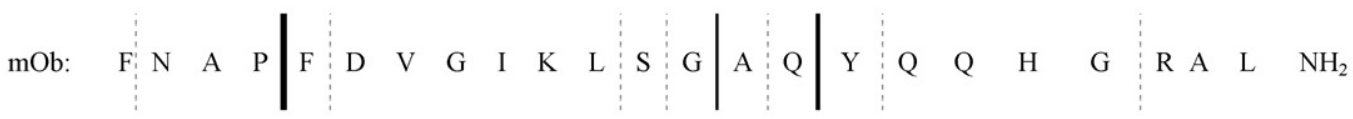

$$
\begin{aligned}
& \begin{array}{lllll|l|lllllll:l|l:l:lllllllllll}
\mathrm{I}_{1} \text { YmOb: } & \text { F } & \text { N } & \text { A } & \text { P } & \text { F } & \text { D } & \text { V } & \text { G } & \text { I } & \text { K } & \text { L } & \text { S } & \text { G } & \text { A } & \text { Q } & I_{1} Y & \text { Q } & \text { Q } & \text { H } & \text { G } & \text { R } & \text { A } & \text { L } & \mathrm{NH}_{2}
\end{array} \\
& \begin{array}{ll|lll|l:l:llllll|l|llllllllllllll}
\mathrm{I}_{2} \mathrm{YmOb}: & \mathrm{F} & \mathrm{N} & \mathrm{A} & \mathrm{P} & \mathrm{F} & \mathrm{D} & \mathrm{V} & \mathrm{G} & \mathrm{I} & \mathrm{K} & \mathrm{L} & \mathrm{S} & \mathrm{G} & \mathrm{A} & \mathrm{Q} & \mathrm{I} 2 \mathrm{Y} & \mathrm{Q} & \mathrm{Q} & \mathrm{H} & \mathrm{G} & \mathrm{R} & \mathrm{A} & \mathrm{L} & \mathrm{NH}_{2}
\end{array} \\
& \begin{array}{ll|l:ll|l|l|lllll:l:l|l:l|l:lllllllllll}
\mathrm{I}_{2} \mathrm{HmOb}: & \mathrm{F} & \mathrm{N} & \mathrm{A} & \mathrm{P} & \mathrm{F} & \mathrm{D} & \mathrm{V} & \mathrm{G} & \mathrm{I} & \mathrm{K} & \mathrm{L} & \mathrm{S} & \mathrm{G} & \mathrm{A} & \mathrm{Q} & \mathrm{Y} & \mathrm{Q} & \mathrm{Q} & \mathrm{I}_{2} \mathrm{H} & \mathrm{G} & \mathrm{R} & \mathrm{A} & \mathrm{L} & \mathrm{NH}_{2}
\end{array}
\end{aligned}
$$

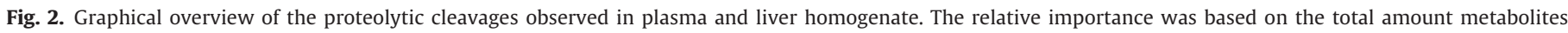

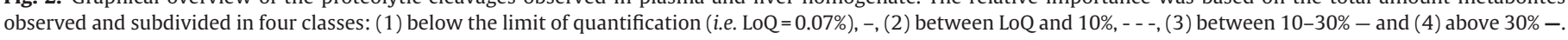

compared to the native peptide. In plasma, the relative importance of this cleavage compared to the total degradants rises from $2.5 \%$ in mouse obestatin to $23.5 \%$ for (3-iodo- $\left.\mathrm{Y}^{16}\right)$-obestatin and further to about $49 \%$ and $34 \%$ in (3,5-diiodo- $\left.Y^{16}\right)$ - and (2,5-diiodo$\mathrm{H}^{19}$ )-obestatin, respectively. Moreover, in plasma, the abundance of cleavages near the $\mathrm{C}$-terminus of the sequence (i.e. $\mathrm{L}^{11}-\mathrm{L}^{23}$ ) was found to generally decrease upon peptide iodination, except for the $\mathrm{R}^{21}-\mathrm{A}^{22}$ bond, which actually increases upon iodination: 9.1\% in unmodified obestatin to $30.8,2.8$ and $32.3 \%$ in the different iodinated derivatives. In liver, a similar effect was observed, together with an inhibition of the $\mathrm{A}^{14}-\mathrm{Q}^{15}$ peptide bond proteolysis for the iodinated obestatin derivatives. The observed deiodination of obestatin was the result of an enzymatic catalysis, and thus not chemically driven, since the chemical control (i.e. incubation of peptide in buffer) did not reveal any presence of deiodinated nor oxidated obestatin peptides. Moreover, in the tissue metabolization samples, no oxidative deiodination products could be observed using EIC-LC-MS.

\section{Discussion}

Upon comparison of the in vitro stability of mouse obestatin and its iodinated derivatives in different biological media, cleavage by proteolytic enzymes was found to be less pronounced for the iodinated peptide. The main enzymes responsible for the production of the metabolites were found to be pepsin, proteinase $\mathrm{K}$, chymotrypsin and thermolysin, belonging to the pepsin A1 family, subtilisin S8, trypsin S1 family and thermolysin M4 family, respectively $[1,22]$. The first three enzymes prefer to cleave after aromatic 

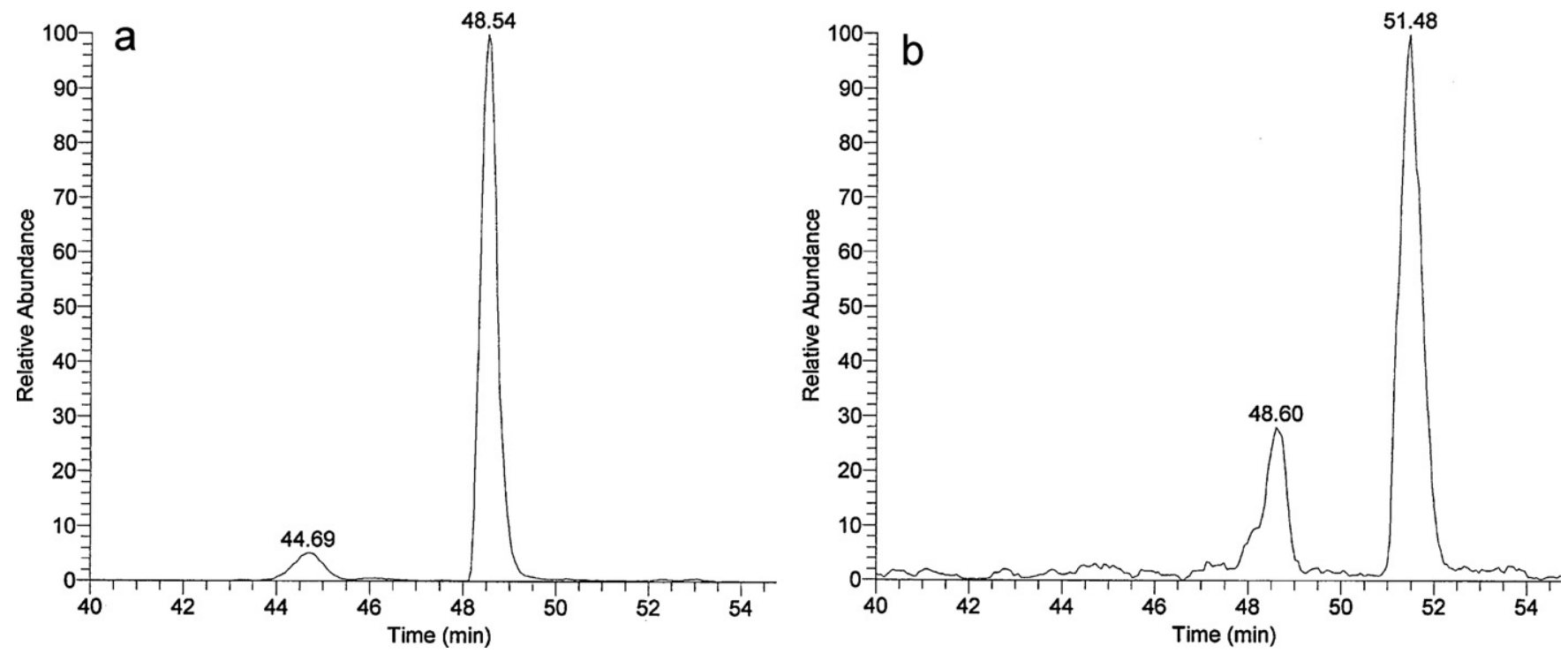

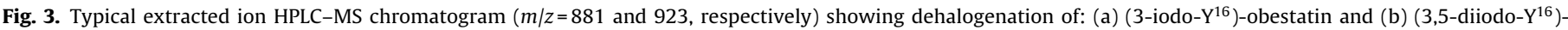
obestatin after incubation for 20 min in mouse plasma. Peaks at $44.7,48.6$ and 51.5 min correspond with non-, mono- and diiodinated peptide, respectively.

amino acids (e.g. Y, W or F) which fit in the hydrophobic pocket of the enzyme. Other amino acids are targeted as well, but at a much lower rate.

Apparently, the relevant proteases are negatively influenced in their catalytic hydrolysis by the supplementary iodine atom(s), but this protease inhibition was compensated by additional dehalogenase activity. This latter phenomenon was found to be mainly associated with plasma and liver, and more strongly affecting the two diiodinated peptides. Our findings show that the diiodotyrosine amino acid residue is more susceptible to dehalogenation than monoiodo-tyrosine, independent of the biological matrix. Moreover, (2,5-diiodo- $\left.\mathrm{H}^{19}\right)$-obestatin was more rapidly dehalogenated compared to (3,5-diiodo- $\left.\mathrm{Y}^{16}\right)$-obestatin.

The presence of such diiodinated species upon obestatin radioiodination may thus give rise to erroneous or even false negative results when used for certain in vitro (e.g. receptor binding) and in vivo (e.g. distribution/imaging, blood-brain-barrier transport, metabolic stability) studies.

Iodine, a scarce micronutrient, is actively salvaged in vertebrates from metabolized compounds for the biosynthesis of thyroid hormones which are essential for normal brain development, growth and metabolism [16]. Enzymatic deiodination of mono- and diiodinated tyrosine and histidine amino acids (MIT, DIT, MIH and DIH, respectively) has been reported to occur both in vitro and in vivo $[8,23]$, with excretion of these iodinated compounds being indicative for certain thyroidal disorders $[9,16]$. To our best knowledge, no direct measurement of in vitro peptide deiodination, yielding extensive sequence information on the metabolites formed has been published yet. Dehalogenation of MIT by thyroid iodotyrosine deiodinase (IYD) was reported to be faster than that of DIT [23], and requires a bound flavin mononucleotide (FMN) for its

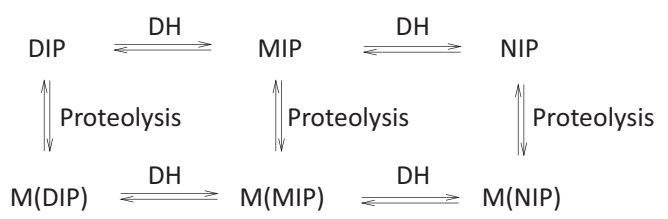

Fig. 4. Schematic presentation of the concept of metabolization, dehalogenation as well as combinations of these processes in iodinated peptides. $\mathrm{DIP}=$ diiodinated peptide, $\mathrm{MIP}=$ monoiodinated peptide, $\mathrm{NIP}=$ noniodinated peptide, $\mathrm{DH}=$ dehalogenation and $\mathrm{M}=$ proteolytic metabolite. catalytic activity. In contrast, iodothyronine deiodinase (ID or DI) requires an active-site Cys for reduced thyroxine generation [7]. These enzymes represent the most common two currently known reductive dehalogenation pathways in mammals (Fig. 6), while cytochrome systems were also described to dehalogenate in an oxidative way $[3,11,12,14]$. This latter enzyme was found not to be responsible for the deiodination of obestatin derivatives because no oxidated fragments were observed in the mass spectra of our samples. When comparing the substrate specificity of IYD to our results on peptide-incorporated iodotyrosines, we demonstrated just the opposite: a larger fraction dehalogenation of diiodo-tyrosine iodinated peptide is obtained compared to that of monoiodo-tyrosine iodinated peptide. This latter finding is thus not only considered to be more consistent with an efficient salvage of iodine atoms, but would also require another enzyme. Furthermore, the conformation of the IYD active site accommodating MIT and DIT is not likely to allow for additional amino acid residues in the pocket surrounding the substrate and FMN as it is stated that there is little or no access possible for solvents [25]. Type I iodothyronine 5 -deiodinase (ID1) presents a broader substrate specificity with a preference L-thyroxine (T4) $\gg 3,3^{\prime}, 5$-triiodothyronine (T3) [15], which is more consistent with our data. The evaluation of the currently known enzymes being possibly the major responsible for the deiodination of obestatin reveals future perspectives, which we are currently investigating.

Although a significantly decreased enzymatic degradation with a more than doubling of its half-life (from 15.7 to $41.5 \mathrm{~min}$ ) is observed for mono-iodinated obestatin in liver homogenate when compared to the native peptide, it is not predictable whether or not this compound will exhibit either an increased or decreased activity: e.g. inactivation by antibodies [21] and altered affinity for its receptor $[13,18]$. In addition to proteolysis or dehalogenation solely, we also demonstrated the occurrence of combinations of dehalogenated metabolites or metabolized dehalogenated peptides. As visualized in our scheme (Fig. 4) and confirmed in our data, deiodination and enzymatic proteolysis processes both occur. Since these dehalogenated proteolytic fragments were not taken into account in the estimation of the percentage dehalogenation, the actual dehalogenated fraction is even higher than our data.

In conclusion, this study demonstrated that the pharmacokinetic profile of tyrosine- and histidine-iodinated mouse obestatin derivatives is not only severely compromised through rapid 


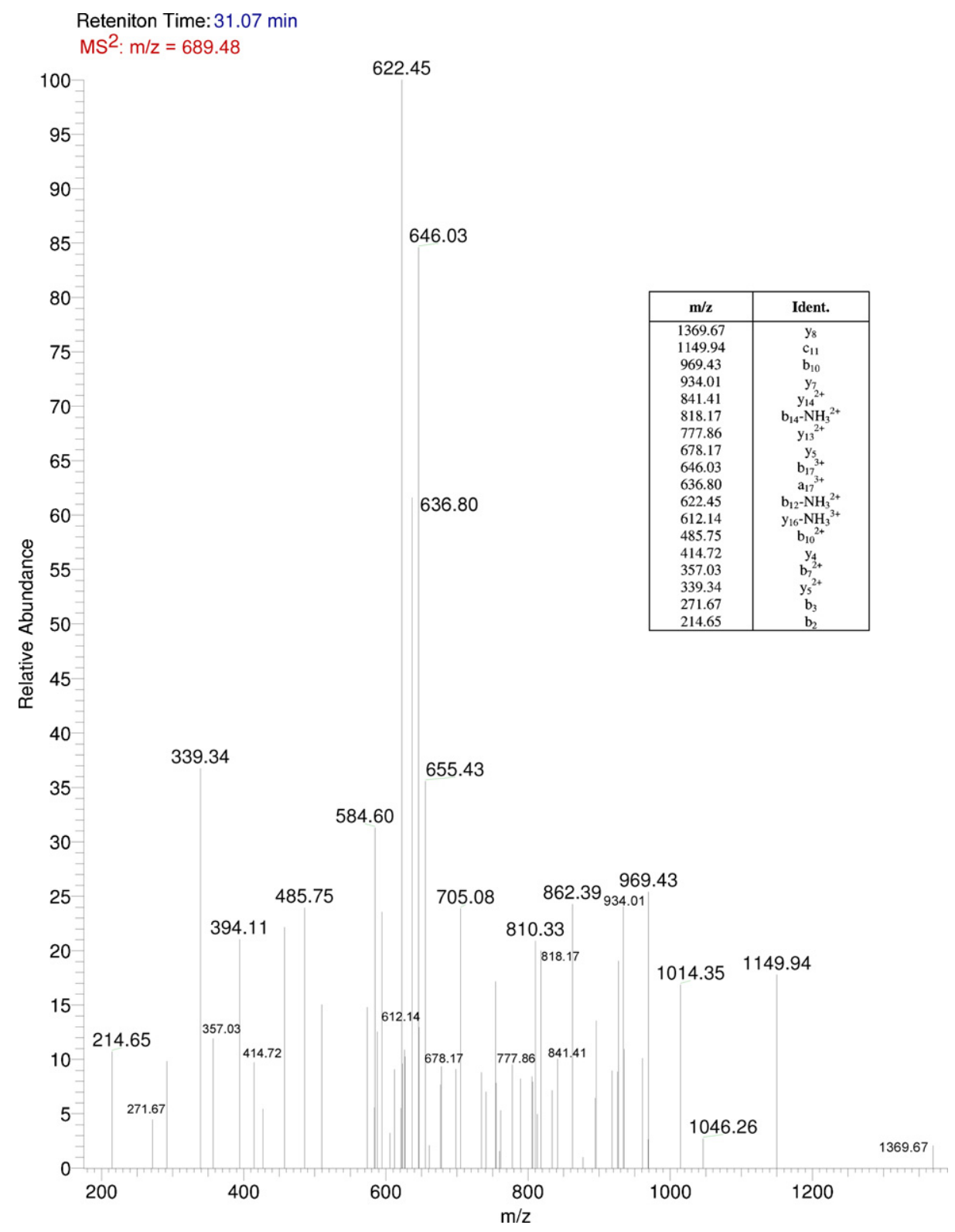

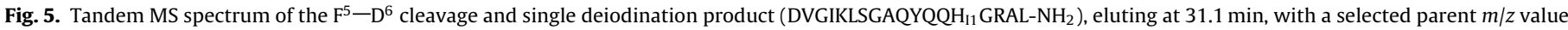
of 689.48 . This metabolite arises from both proteolysis and dehalogenation as observed after incubation of $\left(2,5-\right.$ diiodo- $\left.{ }^{19}\right)$-obestatin during 20 min in mouse plasma.

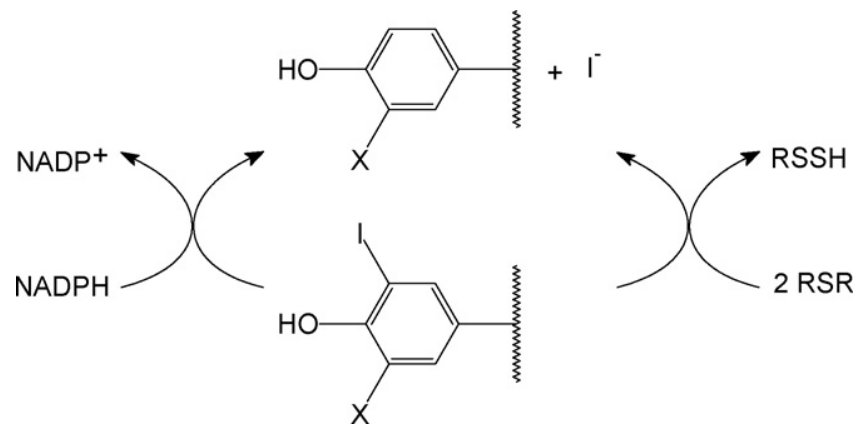

Fig. 6. Enzymatic reductive dehalogenation pathways.

degradation by systemic proteolytic enzymes, but also by dehalogenases. Also, the site-specificity of the proteases is altered by incorporation of iodine atoms. Hence, their use to directly predict the in vivo pharmacokinetics of unmodified peptide is questionable.

\section{Acknowledgements}

This work was supported by the Flemish Institute supporting Scientific-Technological Research in Industry (IWT grant 073402 to S.V.D.) and through the "Functional Peptidomics project" (IWT grant SBO-050164 to V.V. and B.D.S.). Support by the Special Research Fund of Ghent University (01J22510) is acknowledged by E.W. and B.D.S. The authors thank Nadia Lemeire for technical assistance.

\section{Appendix A. Supplementary data}

Supplementary data associated with this article can be found, in the online version, at doi:10.1016/j.peptides.2011.12.010.

\section{References}

[1] Peptide cutter [cited 2011 17-10-2011]. Available from: http://web.expasy. org/peptide_cutter/. 
[2] Agnew A, Calderwood D, Chevallier OP, Greer B, Grieve DJ, Green BD. Chronic treatment with a stable obestatin analog significantly alters plasma triglyceride levels but fails to influence food intake; fluid intake; body weight; or body composition in rats. Peptides 2011;32: 755-62.

[3] Blair E, Greaves J, Farmer PJ. High-temperature electrocatalysis using thermophilic P450 CYP119: dehalogenation of CCl4 to CH4. J Am Chem Soc 2004;126:8632-3.

[4] Bresciani E, Rapetti D, Dona F, Bulgarelli I, Tamiazzo L, Locatelli V, et al. Obestatin inhibits feeding but does not modulate $\mathrm{GH}$ and corticosterone secretion in the rat. J Endocrinol Invest 2006;29:RC16-8.

[5] Carlini VP, Schioth HB, deBarioglio SR. Obestatin improves memory performance and causes anxiolytic effects in rats. Biochem Biophys Res 2007;352:907-12.

[6] De Spiegeleer B, Vergote V, Pezeshki A, Peremans K, Burvenich C. Impurity profiling quality control testing of synthetic peptides using liquid chromatography-photodiode array-fluorescence and liquid chromatography-electrospray ionization-mass spectrometry: the obestatin case. Anal Biochem 2008;376:229-34.

[7] Friedman JE, Watson JA, Lam DWH, Rokita SE. Iodotyrosine deiodinase is the first mammalian member of the NADH oxidase/flavin reductase superfamily. J Biol Chem 2006;281:2812-9.

[8] Goldberg ER, Cohen LA. Models for in vivo deiodination of 2-iodohistidine. Bioorg Chem 1993;21:41-8.

[9] Gons MH, Vijlder J, Canbos TC, Tegelaers WHH. Excretion of iodohistidines, an important laboratory aid for diagnosis of a special type of thyroidal disorder. Pediatr Res 1978;12:158.

[10] Green BD, Irwin N, Flatt PR. Direct and indirect effects of obestatin peptides on food intake and the regulation of glucose homeostasis and insulin secretion in mice. Peptides 2007;28:981-7.

[11] Hackett JC, Sanan TT, Hadad CM. Oxidative dehalogenation of perhalogenated benzenes by cytochrome P450 compound I. Biochemistry 2007;46: 5924-40.

[12] Isin EM, Guengerich FP. Complex reactions catalyzed by cytochrome P450 enzymes. BBA - Gen Subjects 2007;1770:314-29.

[13] Jacobsen RB, DelaCruz RG, Grose JH, McIntosh JM, Yoshikami D, Olivera BM. Critical residues influence the affinity and selectivity of alpha-conotoxin MI for nicotinic acetylcholine receptors. Biochemistry 1999;38:13310-5.

[14] Koe GS, Vilker VL. Effect of oxygen on the dehalogenation of 1,2dibromo-3-chloropropane by cytochrome P450cam (CYP101). Biotechnol Prog 2005;21:1119-27.

[15] Kohrle J. Local activation and inactivation of thyroid hormones: the deiodinase family. Mol Cell Endocrinol 1999;151:103-19.

[16] Kopp PA. Reduce, recycle, reuse - iodotyrosine deiodinase in thyroid iodide metabolism. N Engl J Med 2008;358:1856-9.
[17] Lagaud GJ, Young A, Acena A, Morton MF, Barrett TD, Shankley NP. Obestatin reduces food intake and suppresses body weight gain in rodents. Biochem Biophys Res 2007;357:264-9 [retracted article. See vol. 388, p. 619, 2009]

[18] Loot AE, van Buiten A, Roks AJM, Henning RH. The suitability of iodinated angiotensin-(1-7) peptides as pharmacological tools. J Pharm Technol 2005;51:51-5.

[19] Nagaraj S, Peddha MS, Manjappara UV. Fragment analogs as better mimics of obestatin. Regul Pept 2009;158:143-8.

[20] Nagaraj S, Peddha MS, Manjappara UV. Fragments of obestatin as modulators of feed intake, circulating lipids, and stored fat. Biochem Biophys Res Commun 2008;366:731-7.

[21] Noguchi M, Adachi H, Aoki E, Iida Y, Kasagi K, Endo K, et al. Autoantibody against diiodinated tyrosine-gastrin in a patient with graves-disease. Clin Chem 1987;33:97-9.

[22] Rawlings ND, Barrett AJ. Evolutionary families of peptidases. Biochem J 1993;290:205-18.

[23] Solis SJC, Villalobos P, Orozco A, Valverde RC. Comparative kinetic characterization of rat thyroid iodotyrosine dehalogenase and iodothyronine deiodinase type 1. J Endocrinol 2004;181:385-92.

[24] Subasinghage AP, Green BD, Flatt PR, Irwin N, Hewage CM. Metabolic and structural properties of human obestatin $\{1-23\}$ and two fragment peptides. Peptides 2010;31:1697-705.

[25] Thomas SR, McTamney PM, Adler JM, LaRonde-LeBlanc N, Rokita SE. Crystal structure of iodotyrosine deiodinase, a novel flavoprotein responsible for iodide salvage in thyroid Glands. J Biol Chem 2009;284:19659-67.

[26] Van Dijck A, Van Dam D, Vergote V, De Spiegeleer B, Luyten W, Schoofs L, et al. Central administration of obestatin fails to show inhibitory effects on food and water intake in mice. Regul Pept 2009;156:77-82.

[27] Vergote V, Baert B, Vandermeulen E, Peremans K, van Bree H, Slegers G, et al. LC-UV/MS characterization and DOE optimization of the iodinated peptide obestatin. J Pharm Biomed Anal 2008;46:127-36.

[28] Vergote V, Bodé S, Peremans K, Vanbree H, Baert B, Slegers G, et al. Analysis of iodinated peptides by LC-DAD/ESI ion trap mass spectrometry. J Chromatogr B 2007;850:213-20.

[29] Vergote V, Van Dorpe S, Peremans K, Burvenich C, De Spiegeleer B. In vitro metabolic stability of obestatin: kinetics and identification of cleavage products. Peptides 2008;29:1740-8.

[30] Werle M, Bernkop-Schnurch A. Strategies to improve plasma half life time of peptide and protein drugs. Amino Acids 2006;30:351-67.

[31] Zhang JV, Klein C, Ren P-G, Kass S, Donck LV, Moechars D, et al. Response to comment on obestatin, a peptide encoded by the ghrelin gene, opposes ghrelin's effects on food intake. Science 2007;315:766.

[32] Zhang JV, Ren PG, Avsian-Kretchmer O, Luo CW, Rauch R, Klein C, et al. Obestatin, a peptide encoded by the ghrelin gene, opposes ghrelin's effects on food intake. Science 2005;310:996-9. 